Nig. J. Biotech. Vol. 37(1): 85-93 (June 2020)

ISSN: 01891731

Available online at

http://www.ajol.info/index.php/njb/index

and www.biotechsocietynigeria.org

DOI: https://dx.doi.org/10.4314/njb.v37i1.9

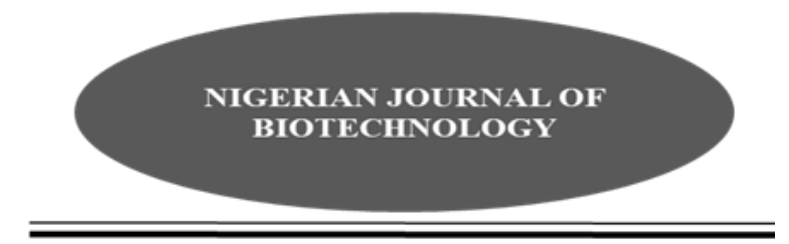

\title{
Responses of African yam bean (Sphenostylis stenocarpa [Hochst. Ex A. Rich]) accessions to viral diseases and serological identification of the associated viruses
}

\author{
${ }^{* 1}$ Ogunsanya, O.M., ${ }^{1}$ Afolabi, C.G., ${ }^{1}$ Otusanya, M. 0., ${ }^{2}$ Adebisi, M. A. \\ 1 Department of Crop Protection, Federal University of Agriculture, Abeokuta, Nigeria, \\ 2. Department of Plant Breeding and Seed Technology, Federal University of Agriculture, Abeokuta, \\ Nigeria.
}

\begin{abstract}
African yam bean (Sphenostylis stenocarpa) is an orphan crop with lofty nutraceutical benefits grown in Africa. However, pests and diseases often hinder its productivity. Twenty accessions of African yam bean (AYB) were screened for resistance to viral diseases and symptomatic leaves were indexed for the presence of viruses. The Field experiments were conducted during the 2015/2016 cropping seasons (wet and dry seasons). The twenty accessions were grown in triplicates in a randomized complete block design (RCBD) on the field under natural infection and the resistance or susceptibility responses were recorded using visual symptom expression. The characteristic symptoms that were highly prevalent were leaf mosaic and leaf distortion. In both seasons, there were significant $(P<0.05)$ differences in the severity of these viral symptoms. Also, based on the severity of the symptoms observed in this study, 2 accessions were classified as resistant, 16 as susceptible and 2 accessions as highly susceptible. Two viruses were identified serologically namely Cowpea Mild Mottle Virus (CPMMV) and Blackeye Cowpea Mosaic Virus (BICMV). The sources of resistance identified in this study would be useful for breeders in developing virus resistant varieties for African yam bean improvement.
\end{abstract}

Keywords: African yam bean, Virus, Symptoms, ACP-Elisa, Screening.

*Corresponding Author: ogunsanyaolaide@rocketmail.com

\section{Introduction}

African yam bean (AYB; Sphenostylis st enocarpa) is a tuberous legume which belongs to the family Fabaceae. It is also known as Diegemtenguere (Mali), Norouko and Roya (Sudan), Okpududu and Azanma (Igbo, Nigeria), Girigiri (Hausa, Nigeria) and Sese (Yoruba, Nigeria). It is mostly grown in Central (Gabon and Congo) and Western Africa (Nigeria, Cameroon,
Togo, Ghana, and Ivory Coast). Nigeria is more prominent for AYB production, as it is extensively cultivated in the western, eastern, southern and northern states of the country (Abbey and Berezi, 1998; Saka and Ajibade, 2004). AYB is mostly cultivated as a mixed crop with cassava, vegetables, yam and rice. The tubers of this crop possess higher protein content than sweet potato, Irish potato, yam, and cassava (Amoatey et al., 2000). AYB records a higher amino acid 
content compared to pigeon pea, cowpea, and bambara groundnut (Uguru and Madukaife, 2001). Despite its importance, as a crop with enormous potentials to provide food, feed, medicines, and insecticides for humans and livestock (Adewale et al., 2008), it remains a neglected crop (Adewale et al., 2012).

Its long maturation period, long cookability, need for stakes and high incidence of pests and diseases inspired its stigmatization as "neglected crop." These long jams subjected it to less research and farming attention thereby depriving it of a good breeding program and commercialization of research outputs (Adewale et al., 2012), despite its qualification as a crop with scientific and economic benefits.

Pest and disease complex results in poor yield of AYB, which is one of the significant factors that affect productivity (Okigbo, 1973; Kay, 1987; Ameh and Okezie, 2005; Agu, 2008; Ogah, 2011). In Nigeria, unidentified viral diseases were reported to cause leaf malformation, leaf discoloration, leaf curl and plant stunting in AYB. Viral infected plants produced little or no flowers and pods (Ameh and Okezie, 2005). In order to appropriately and effectively manage the poor yield resulting from this infection, it is important to accurately diagnose the disease. Furthermore, the most efficient, feasible and cost-effective way of controlling legume viruses is through the development of resistant varieties (Taiwo, 2003). However, in past studies of viral diseases associated with $A Y B$, there was no report of resistant sources or possible resistance to these diseases, which is a very important baseline information in any disease resistance breeding program.

Thus, this is a preliminary study, conducted to evaluate 20 accessions of AYB for possible sources of resistance to viral infection under natural field conditions and also to index associated viruses.

\section{Materials and methods}

\section{Research location and planting materials}

The field experiment was carried out at the Teaching and Research Farm of the Federal University of Agriculture, Abeokuta in Ogun State, Nigeria (Lat $7{ }^{\circ} \mathrm{N}$, Long $3^{\circ} 231 \mathrm{E}$ ). Twenty accessions of AYB were planted in the wet season (2015) while sixteen AYB accessions were planted in the dry season (2015/2016) due to unavailability of the remaining four accessions in the gene bank. African yam bean seeds used in this study were sourced from the Genetic Resources Centre, International Institute of Tropical Agriculture, Ibadan.

\section{Land preparation and experimental design}

Prior to crop cultivation the land was cleared, ploughed twice and harrowed using a tractor. Field trials were conducted during the wet and dry seasons of 2015/2016 cropping periods. The wet season commenced in June and terminated in November 2015 and the dry season commenced in December 2015 and terminated in May 2016. The experiment was laid out in a Randomised Complete Block Design (RCBD) which was replicated three times. The total size of the field was $2649 \mathrm{~m}^{2}$ while the size of the plot was $14 \mathrm{~m}$ by $20 \mathrm{~m}$ with a $1 \mathrm{~m}$ space between plants and $0.7 \mathrm{~m}$ within plants. Line planting method was adopted to sow the African yam bean seeds; the planting density was 20 plants per plot .

The AYB seeds were sown on a loamy soil without fertilizer and herbicide application during both seasons. Staking of vines was carried out 3 weeks after planting and manual weeding was done when necessary, within the duration of the experiments. During the dry season, plants were planted in a Fadama area (a land that floods in the rainy season and its irrigable) and irrigated twice daily when necessary with watering can (early in the morning and in the cool evening).

\section{Assessment of disease severity}

Data were collected on the severity of the viral diseases. Diseases were rated on a scale of 0-4; $0=$ no symptom, $1=$ Mild mosaic with yellow mosaic, $2=$ Moderate mosaic without significant distortion, $3=$ Moderate mosaic with significant distortion, $4=$ Severe mosaic symptoms, distortion with stunting.

Disease rating scale was determined with disease scores of $0-0.99$ (Highly resistant); $1.0-1.99$ (Resistant); 2.0 - 3.99 (Susceptible); 4.0 and above (Highly susceptible). 
Indexing Africa yam Bean for Viruses using Antigen Coated Plate (ACP) Enzyme linked immunosorbent assay (ELISA) Method

The serological protocol employed to detect the viruses infecting African yam bean was the Antigen-coated plate (ACP) ELISA method described by Kumar (2009). The leaf samples collected from the field were tested using antibodies specific for Cowpea aphid borne mosaic virus (CABMV), Blackeye cowpea mosaic virus (BICMV), Cucumber mosaic virus (CMV), Southern bean mosaic virus (SBMV), Cowpea mottle virus (CPMoV), Cowpea yellow mosaic virus (CYMV), Cowpea mild mottle virus (CPMMV), since AYB belongs to the same family as cowpea.

\section{Data analysis}

Data collected on disease severity were subjected to analysis of variance, and significant means were compared using Duncan multiple range test (DMRT) at $5 \%$ probability level.

\section{Results}

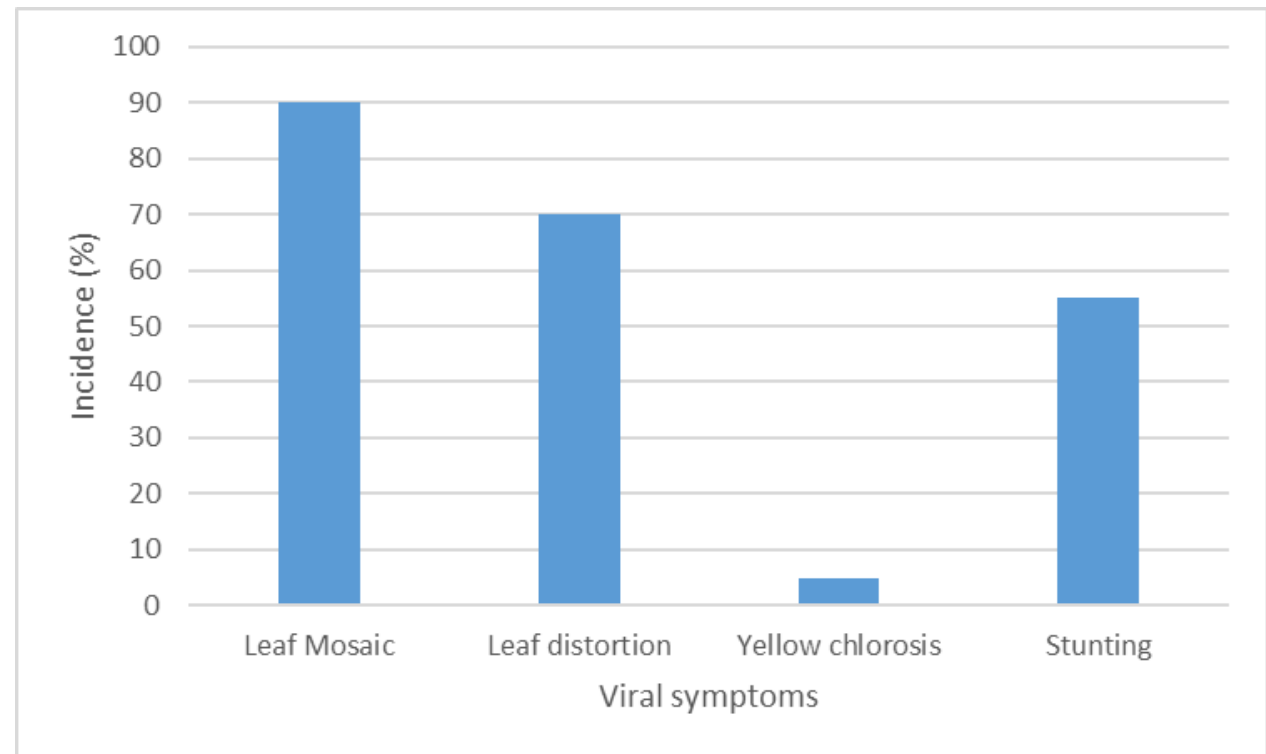

Fig 1: Incidence of characteristic viral symptoms observed in 20 accessions of African yam bean in two planting seasons (wet and dry seasons) 

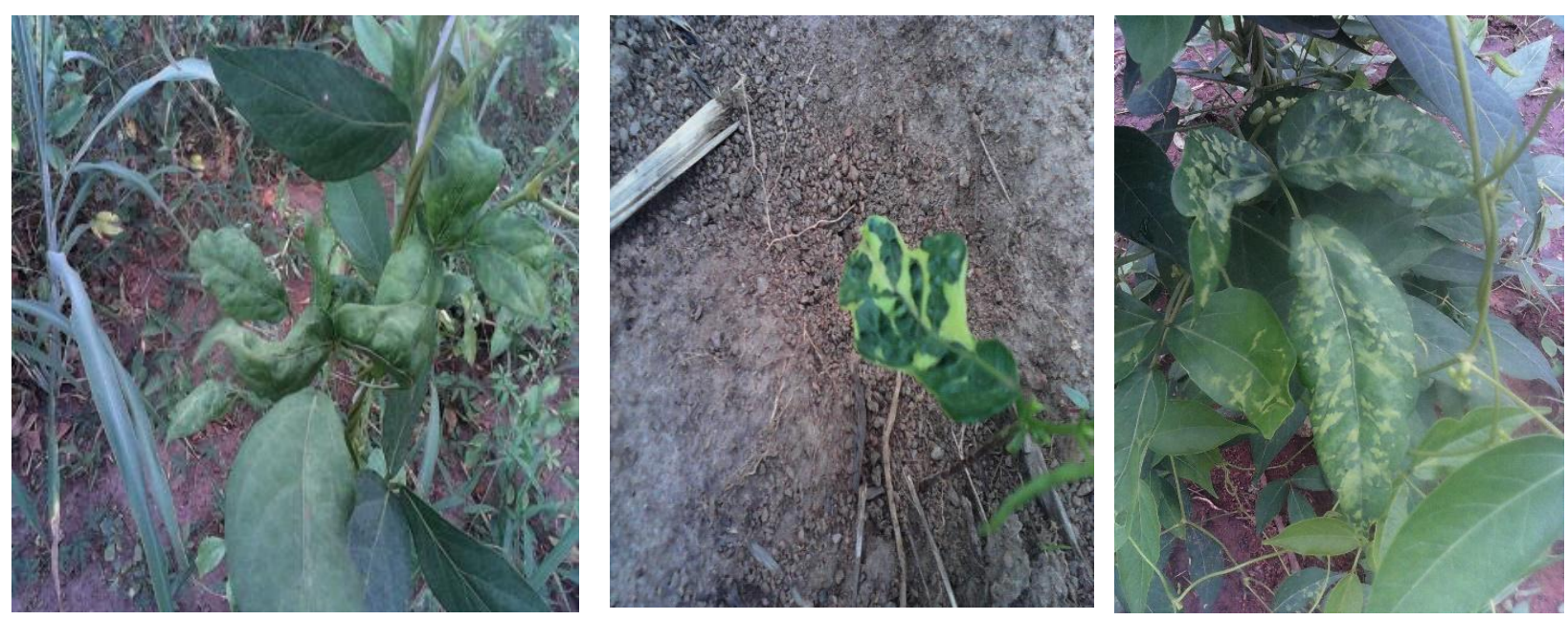

Plate 1: Characteristic viral symptoms observed on African yam bean leaves

Table 1: Severity of characteristic viral symptoms on African yam bean during wet (2015) and dry (2015/2016) seasons.

\begin{tabular}{lll}
\hline & \multicolumn{2}{l}{ Severity } \\
\cline { 2 - 3 } Accessions & Wet & Dry \\
\hline TSs 1 & $4.15^{\mathrm{a}}$ & $2.83^{\mathrm{bc}}$ \\
TSs 10 & $0.00^{\mathrm{b}}$ & $3.23^{\mathrm{ab}}$ \\
TSs 10A & $3.25^{\mathrm{a}}$ & $\mathrm{NA}$ \\
TSs 23 & $4.40^{\mathrm{a}}$ & $3.40^{\mathrm{a}}$ \\
TSs 24 & $4.03^{\mathrm{a}}$ & $3.00^{\mathrm{abc}}$ \\
TSs 33 & $3.45^{\mathrm{a}}$ & $2.80^{\mathrm{bc}}$ \\
TSs 40A & $3.90^{\mathrm{a}}$ & $\mathrm{NA}$ \\
TSs 48 & $4.75^{\mathrm{a}}$ & $\mathrm{NA}$ \\
TSs 49 & $0.00^{\mathrm{b}}$ & $3.00^{\mathrm{abc}}$ \\
TSs 57 & $3.00^{\mathrm{a}}$ & $2.90^{\mathrm{abc}}$ \\
TSs 58 & $4.15^{\mathrm{a}}$ & $2.80 \mathrm{bc}$ \\
TSs 61 & $4.07^{\mathrm{a}}$ & $2.90^{\mathrm{abc}}$ \\
TSs 67 & $4.00^{\mathrm{a}}$ & $2.90^{\mathrm{abc}}$ \\
TSs 69 & $4.20^{\mathrm{a}}$ & $2.97^{\mathrm{abc}}$ \\
TSs 7A & $2.40^{\mathrm{ab}}$ & $2.60^{\mathrm{c}}$ \\
TSs 82 & $4.35^{\mathrm{a}}$ & $2.83^{\mathrm{bc}}$ \\
TSs 84 & $4.35^{\mathrm{a}}$ & $2.80^{\mathrm{bc}}$ \\
TSs 86 & $2.50^{\mathrm{ab}}$ & $3.17^{\mathrm{ab}}$ \\
TSs 89 & $4.35^{\mathrm{a}}$ & $3.00^{\mathrm{abc}}$ \\
TSs 9 & $3.83^{\mathrm{a}}$ & $\mathrm{NA}$ \\
\hline T & &
\end{tabular}

Means within the same column followed by the same letter are not significantly different at $\mathrm{P}<0.05$ (DMRT) 
TSs $=$ Tropical Sphenostylis stenocarpa

$\mathrm{NA}=$ Not available

Table 2: Disease reaction of AYB accessions to viral diseases during wet (2015) and dry (2015/2016) seasons

\begin{tabular}{lll}
\hline Accessions & Pooled Severity means & Disease reaction \\
\hline TSs 1 & 4.91 & $\mathrm{HS}$ \\
TSs 10 & 1.62 & $\mathrm{R}$ \\
TSs $10 \mathrm{~A}$ & 3.25 & $\mathrm{~S}$ \\
TSs 23 & 3.9 & $\mathrm{~S}$ \\
TSs 24 & 3.52 & $\mathrm{~S}$ \\
TSs 33 & 3.13 & $\mathrm{~S}$ \\
TSs $40 \mathrm{~A}$ & 3.9 & $\mathrm{~S}$ \\
TSs 48 & 4.75 & $\mathrm{HS}$ \\
TSs 49 & 1.5 & $\mathrm{R}$ \\
TSs 57 & 2.95 & $\mathrm{~S}$ \\
TSs 58 & 3.48 & $\mathrm{~S}$ \\
TSs 61 & 3.49 & $\mathrm{~S}$ \\
TSs 67 & 3.45 & $\mathrm{~S}$ \\
TSs 69 & 3.59 & $\mathrm{~S}$ \\
TSs $7 \mathrm{~A}$ & 2.5 & $\mathrm{~S}$ \\
TSs 82 & 3.59 & $\mathrm{~S}$ \\
TSs 84 & 3.58 & $\mathrm{~S}$ \\
TSs 86 & 2.84 & $\mathrm{~S}$ \\
TSs 89 & 3.68 & $\mathrm{~S}$ \\
TSs 9 & 3.83 & $\mathrm{~S}$ \\
\hline TS $=$ &
\end{tabular}

TSs= Tropical Sphenostylis sternocarpa;

$\mathrm{NA}=$ Not available

$\mathrm{R}=$ Resistant

$\mathrm{S}=$ Susceptible

HS= Highly susceptible

Serological identification of Viruses associated with $A Y B$ using Enzyme-linked immunosorbent assay

During the first planting (wet) season using the bulk sampling method, none of the 20 symptomatic AYB leaf samples tested positive $(0 \%)$ to the seven antibodies used in this study. However, during the second planting (dry) season, it was observed that 15 of the 16 symptomatic samples tested positive to CPMMV and BICMV.

CPMMV was recorded as the most prevalent virus with an incidence of $93.8 \%$ while BICMV was the least prevalent $(6.3 \%)$. However, one sample $(6.3 \%)$ tested positive for the combination of two viruses (CPMMV and BICMV). 
Ogunsanya et al./ Nig. J. Biotech. Vol. 37 Num. 1 : 85-93 (June 2020)

Table 3: Occurrence of single and mixed virus infections on AYB leaf samples in first the (2015) and second (2015/2016) planting seasons

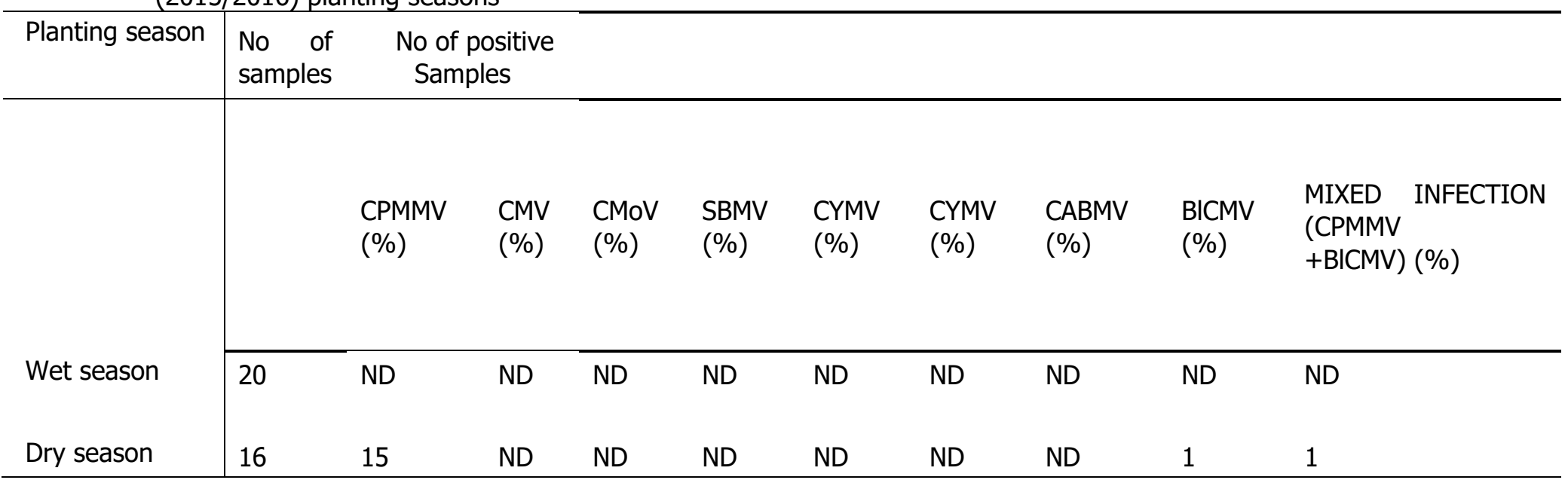

$\mathrm{ND}=$ Not detected.

CABMV= Cowpea Aphid borne mosaic virus

$\mathbf{C Y M V}=$ Cowpea yellow mosaic virus

$\mathbf{C P M M V}=$ Cowpea mild mottle virus

$\mathbf{C M o V}=$ Cowpea mottle virus

SBMV=Southern bean mosaic virus

$\mathbf{C M V}=$ Cucumber mosaic virus

$\mathbf{B I C M V}=$ Blackeye cowpea mosaic virus

\section{Discussion}

In this study, evaluation of AYB accessions to viral infection was based on visual symptom expression only. The symptoms (leaf mosaic and leaf distortion) observed to be highly prevalent in AYB in this study corroborate the viral symptoms observed on most legumes especially cowpea (Vanderborght and Baudoin, 2001 and Akinjogunla, 2005). This evaluation showed that two accessions exhibited resistance to the viral infection, other accessions were either susceptible or highly susceptible. This means that most of the accessions used in this study cannot be incorporated in any disease resistant breeding program. Although, field screening for resistance under natural viral infection cannot rely only on visual symptoms, as it has been postulated that different viruses exhibit similar symptoms. More so, some plants show virus-like symptoms due to nutritional deficiency, unfavorable weather condition, pest infestation, genetic abnormality, herbicide toxicity, insect or mite infestation (Naidu and Hughes, 2003).

ELISA detected no virus in the AYB samples collected in the first planting season (rainy season). However, 2 viruses which corroborate the reports of Hughes et al. (2003) and Ghorbani et al. (2007) were identified in the AYB leaf samples collected in the second planting season (dry season) namely CPMMV and BICMV. CPMMV is a member of the genus Carlavirus, which has been reported to cause leaf distortion 
and it is usually transmitted by whitefly (Bemisia tabacl) in a non-persistent manner (Laguna et al.,2006; Jeyanandarajah and Brunt, 1993). In this study, CPMMV recorded a high rate of occurrence, probably because of the large population of white flies in the environment due to the presence of alternate hosts near the crop. This observation verifies the report of ElHammady et al. (2004) who reported that Solanum incanum L. acted as a perennial reservoir of CPMMV.

Blackeye cowpea mosaic virus (BICMV) is a seedborne potyvirus which was first described to cause mosaic disease of cowpea by Anderson (1955), it was also detected in bambara groundnut by Thottappilly (1997). The low rate of occurrence of BICMV agrees with the study of Alegbejo and Kashina's (2001), on viruses of cowpea in Nigeria. They also reported a low occurrence of BICMV in cowpea. Furthermore, this virus was reported by Alegbejo and Kashina (2001), to be transmitted by Aphids (Aphis craccivora), an insect that infests $A Y B$ at the vegetative stage (Ameh and Okezie, 2005). The incidence of these viruses in the dry season, might have been as a result of the low relative humidity, which probably could have inhibited quick recovery in AYB genotypes (Edema et al., 1997).

Furthermore, the ELISA results showed that some of the viruses occurred in mixtures such as CPMMV and BICMV in one sample. This result partially complies with the findings of Aliyu (2012) in which mixed infections such as Blackeye cowpea mosaic virus (BICMV) and Cowpea aphid borne mosaic virus (BICMV + CABMV) were detected in the cowpea leaf samples surveyed. Mixed viral infection is not a rare occurrence in field trials especially experiments conducted under natural infection. This kind of infection often alter and complicate symptom expression, thereby impeding a successful symptom-based field diagnosis (Aliyu et al., 2012)

The inability to detect viruses in the AYB leaf samples collected during the wet season from all the 20 accessions could probably have resulted from low virus concentration in the AYB leaves, time of planting, AYB genetic abnormality, unfavorable weather conditions which curtail insect transmission or non-availability of the precise antibodies to detect the virus in symptomatic AYB leaves, just as Aliyu et al. (2012) reported . The absence of CPMMV and BICMV in the wet season might be due to the weather condition as the low temperature and high relative humidity might have also inhibited the quick development of the vectors transmitting these viruses thereby impeding the transmission of these viruses in African yam bean genotypes. More so, due to the favorable weather conditions for the plant, it is possible that the AYB genotypes got to recover from the infection speedily (Tettey et al., 2018).

\section{Conclusion and Recommendation}

African yam bean is a crop with great potential , considering its economic and research benefits. However, its susceptibility to viral diseases as shown in this study, can be devastating to its large-scale production for human and animal use. Due to the negative effects of chemicals to the environment and the fact that insecticides have been reported to be partially effective on the responsible vectors, efforts should be directed towards producing virus-free seeds and developing disease resistant varieties. However, the development of good disease resistant varieties is reliant on accurate virus identification and appropriate germplasm evaluation. Therefore, large-scale screening should be conducted in order to identify more possible sources of resistance. More so, the presumed resistance sources identified in this study should be further confirmed under screen house and field conditions using mechanical inoculation, serological and molecular methods such as real time polymerase chain reaction (RT-PCR) to detect the presence of the virus and quantity of the virus load after inoculation. This will ensure its suitability for use in any disease resistance breeding program for AYB improvement.

\section{Declaration of Competing Interest}

The authors have no conflict of interest.

\section{Acknowledgements}

Appreciation goes to the Genetic Resources Centre, International Institute of Tropical Agriculture, Ibadan for providing the AYB accessions used in this study.

\section{References}


Abbey, B. W. and Berezi, P. E. (1988). Influence of processing on the digestibility of African yam bean (Sphenostylis stenocarpa (Hoechst Ex. A. Rich.)Harms) flour. Nutritional Report International 37:819-827.

Adewale, B. D., Kehinde, O. B., Odu, B. O. and Dumet, D. J. (2008). The potentials of African yam bean (Sphenostylis stenocarpa Hochst.ex.

A. Rich) Harms in Nigeria: character distribution and genetic diversity. In: Smart, J. and Haq, N. (eds.). New Crops and Uses: Their role in a rapidly changing world. Centre for Underutilised Crops. RPM Print and Design Chichester pp 265276

Adewale, B. D., Dumet, D. J., Vroh-Bi, I., Kehinde, O. B., Ojo, D. K., Adegbite, A. E. and Franco, J. (2012). Morphological diversity analysis of African yam bean and prospects for utilization in germplasm conservation and breeding. Genetic Resources and Crop Evolution 59(5): 927-936. http://dx.doi.org/10.1007/s10722-011-9734-1

Agu, C. M. (2008). Effects of organic manure types on root-gall nematodes diseases on African yam bean yield. J. of American Sci. 4: 76-79.

Akinjogunla, O. J. (2005). Effects of single and mixed inoculation with viruses on symptomatology, growth, yield and nutritive content of cowpea: (Vigna unguiculata) M.Sc. Thesis. University of Lagos, Nigeria

Alegbejo, M. D. and Kashina, B.D. (2001). Status of legume viruses in Nigeria. J. Sustainab. Agric. 18: 55-69.

Aliyu, T. H.,Balogun, O. S. and Kumar, L. (2012). Survey of the symptoms and viruses associated with cowpea (vigna unguiculata (L).) in the agroecological zones of kwara state, Nigeria. Ethiopian J. Env. Std. Manag. 5(4): 613-619.

Ameh, G. I. and Okezie, C. E. A. (2005). Pests and diseases of African yam bean, Sphenostylis stenocarpa (Hoechst. ex A. Rich) harms Biological Research 3(1): 14-20.

Amoatey, H. M., Klu, G. Y. P., Bansa, D., Kumaga, F. K., Aboagye, L. M., Benett, S. O. and
Gamedoagbao, D. K. (2000). African yam bean (Sphenostylis stenocarpa) a neglected crop in Ghana. West Afr. J. Apl. Eco. 1: 53-60.

Anderson, C.W. (1955). Vigna and Crotolaria viruses in Florida, II. Notations concerning cowpea mosaic virus (Marmor vignae). Plant Disease Reporter 39: 349-353.

Edema, R., Adipala, E. and Florini, D. A. (1997). Influence of season and cropping system on occurrence of cowpea diseases in Uganda. Plant Dis. 81:465-468

El-Hammady, M., Albrechtsen, S. E., Abdelmonem A. M., Abo El-Abbas F.M. and Gazalla W (2004). Seed-borne cowpea mild mottle virus on soybean in Egypt. Amin University, Cairo. Arab J. Agric. Sci. 12 (2): 838850.

Ghorbani, S. G. M., Shahraeen, N., Elahinia, A. and Bananej, K. (2007). Identification of mixed viral infection on cowpea (Vigna unguiculata) in Guilan province. Proceedings of the second Iranian Microbiology Congress, Alzahra University, Tehran, Iran, p 110.

Hughes, J. d'A. and Shoyinka, S.A. (2003). Overview of viruses of legumes other than groundnut in Africa. In: Plant virology in sub-Saharan Africa. Proceeding Conference, Organized by IITA. J. d'A. Hughes and J. Odu, (eds). International Institute of Tropical Agriculture, Ibadan, Nigeria. pp 553-568.

Jeyanandarajah, P. and Brunt, A. A. (1993). The natural occurrence, transmission, properties and possible affinities of Cowpea mild mottle virus. $J$. Phytopathol. 137: 148-156.

Kay, D. E. (1987). (revised by Gooding, E. G. B.). Crop and Product Digest No. 2 - Root Crops. Tropical Development and Research Institute, London.

Kumar, L. (2009). Methods for the diagnosis of Plant Virus diseases, laboratory Manual. IITA. 94p. 
Laguna, I.G., Arneodo, J.D., Rodriguez-Pardina, P. and Fiorona, M. (2006). Cowpea mild mottle virus infecting soybean crops in North-Western Argentina. Fitop. Brasilia 31(3): 317.

Naidu, R.A. and Hughes, J. A. (2003). Plant virology in sub-Saharan Africa. Proceedings of the Conference of International Institute of Tropical Agriculture, June 4-8, 2001, Ibadan, Nigeria, pp: 233-260.

Ogah, E. O. (2011). Assessing the Impact of Varietal Resistance and Planting Dates on the Incidence of African Yam bean Flower Thrips (Megalurothrips sjostedi, Hochst. Ex.A. Rich) in Nigeria. Asian J. Plt Sci. 1682-394

Okigbo, B. N. (1973). Introducing the yam bean (Sphenostylis stenocarpa) (Hochst ex. A. Rich.) Harms. Proceedings of the first IITA Grain Legume Improvement Workshop (29 October-2 November 1973) Ibadan. Nigeria. pp. 224-238.

Saka, J. O. and Ajibade, S. R. (2004). Survey of underutilized grain legume production systems in the Southwest agricultural zone of Nigeria. J. Agric. Food Info. 6: 93-108.

Taiwo, M.A. (2003). Viruses Infecting Legumes in Nigeria: Case History. In: Plant Virology in SubSaharan Africa, Hughes, J.A. and B.O. Odu (Eds.).
International Institute of Tropical Agriculture, Ibadan, Nigeria, pp: 365-380.

Tettey, C.K., Asare-Bediako, E., Asare, T. A. and Amoatey, H. (2018). Phenotypic screening of Cowpea (Vigna Unguiculata (L. Walp) genotypes for resistance to Cowpea viral diseases. African journal of Food, Agriculture, Nutrition and Development. 18 (2): 13502 - 13524. Doi: 10.18697/ajfand.82.17160

Thottappilly, G and Rossel, H. W. (1997). Identification and Characterization of viruses infecting Bambara groundnut (Vigna subterranean) in Nigeria. Int. J. Pest Manag. 43 (3) 177 - 185

Uguru, M. I. and Madukaife S. O. (2001). Studies on the variability in agronomic and nutritive characteristics of African Yam bean (Sphenostylis sternocarpa Hochst ex. A. Rich. Harms). Plt prod. Res. J 6:10-19

Vanderborght, T. and Baudoin, J. P. (2001). Cowpea [Vigna unguiculata (L.) Walpers]. In R.H. Raemaekers (ed.) Crop production in Tropical Africa, Directorate General for International Cooperation (DGIC), Brussels Belgium pp 372377. 